\title{
Impact of filamentous cyanobacteria on the water quality of two tropical reservoirs
}

\section{Impacto de cianobactérias filamentosas na qualidade da água de dois açudes tropicais}

\author{
Mario Ubirajara Gonçalves Barros ${ }^{1}$, Ismael Keslley Carloto Lopes ${ }^{1}$, \\ Stella Maris de Castro Carvalho ${ }^{2}$ and José Capelo Neto ${ }^{1}$ \\ ${ }^{1}$ Universidade Federal do Ceará, Fortaleza, CE, Brazil \\ ${ }^{2}$ Companhia de Água e Esgoto do Ceará, Fortaleza, CE, Brazil \\ E-mails: mariobarros86@hotmail.com (MUGB),carlotolopes@gmail.com (IKCL), \\ stella.carvalho@cagece.com.br (SMCC), capelo@ufc.br (JCN)
}

Received: May 27, 2016 - Revised: October 26, 2016 - Accepted: November 20, 2016

\begin{abstract}
Artificial lakes play an important role in water availability in tropical semi-arid Northeastern Brazil. However, in addition to the negative effects that dams have on the water quality of rivers, other practices such as discharge of untreated wastewater, intensive crop fertilization and fish farming have been contributing to water quality deterioration. Climate change may be another driver of water quality decrease. Increases in precipitation and drought intensities as well as temperature increase may redefine the dynamics of planktonic communities and favour species more adapted to the new environment. Water samples were collected in two reservoirs selected based on the recurrence of positive results for saxitoxins, Acarape do Meio (AM) and Sitios Novos (SN). In general, diversity in SN (1.08) was higher than in the AM (0.60). Phytoplankton dynamics in these reservoirs differ from other reservoirs in the same region of Brazil, in the sense that filamentous cyanobacteria are dominant. Furthermore, lower diversity, concentration and richness of chlorophyceae and bacillariophyceae were found in both reservoirs. Increase in diversity was observed during the intense rainy season of 2011, suggesting a slight improvement of water quality. A close inverse correlation between Cylindrospermopsis sp and other cyanobacteria was found in $\mathrm{SN}\left(\mathrm{R}^{2}=-0.862\right)$ and in $\mathrm{AM}\left(\mathrm{R}^{2}=-0.997\right)$ and the data collected demonstrates that a season with intensive rainfall may lead to lower cyanobacteria concentrations probably due to water dilution and higher flushing rates.
\end{abstract}

Keywords: Artificial reservoirs; Freshwater cyanobacteria; Semi-arid regions; Temporal phytoplankton dynamics; Eutrophication.

\section{RESUMO}

Os lagos artificiais tem um papel primordial na disponibilidade hídrica no semi-árido Brasileiro. Entretanto, além dos efeitos negativos que os barramentos dos rios causam sobre a qualidade da água, a descarga de esgotos, a irrigação e a piscicultura intensivas vêm acentuando a deterioração da qualidade da água em um ritmo sem precedentes nesta região. A mudança climática é outro fator de impacto negativo na qualidade da água. O aumento da intensidade das precipitações pode redefinir a dinâmica das comunidades de plâncton e espécies mais adaptadas a ambientes extremamente variáveis. Os reservatórios estudados, Acarape do Meio (AM) e Sítios Novos (SN), foram selecionados com base na recorrência de resultados positivos para saxitoxinas. A dinâmicas do fitoplâncton encontrada, difere de outras áreas da mesma região, no sentido em que as cianobactérias filamentosas são dominantes. Baixas diversidade, concentração média e riqueza de Chlorophyceae e Bacillariophyceae foram encontrados em ambos os reservatórios, embora tenha sido observado um aumento durante o intenso período chuvoso de 2011, sugerindo uma ligeira melhoria da qualidade da água. Em geral, a diversidade no reservatório SN $(1,08)$ foi maior que no AM $(0,60)$. Uma correlação inversa entre a concentração de Cylindrospermopsis sp e outras cianobactérias foi encontrada nos reservatórios $\mathrm{SN}\left(\mathrm{R}^{2}=-0,862\right)$ e AM $\left(\mathrm{R}^{2}=-0,997\right)$. Estações de chuvas intensas podem reduzir as concentrações de cianobactérias devido, provavelmente às elevadas taxas de diluição e renovação da água.

Palavras-chaves: Reservatórios artificiais; Cianobactéria de água doce; Região semiárida; Dinâmica temporal de fitoplâncton; Eutrofização. 


\section{INTRODUCTION}

A large number of artificial reservoirs have been constructed to minimize the impacts of prolonged droughts and to meet the increasing water demand in the tropical semi-arid region of Northeastern Brazil (MOURA et al., 2012). These lakes are used for different purposes such as drinking water supply, irrigation, fish farming, and recreation. Nogueira et al. (2010) observed the effects of the dams constructed in Paranapanema River on the structure of phytoplankton and pointed out that they had a negative effect on the richness of these organisms. Discharge of nutrients into water bodies have been reported to increase phytoplankton density, especially cyanobacteria (PIZZOLON et al., 1999; NOGUEIRA et al., 2010; GOWEN et al., 2012). Furthermore, Chellappa and Costa (2003) found that the intensive fish-farming in a northeastern Brazil reservoir provided favorable conditions for the dominance of cyanobacteria. The presence of cyanobacteria is indicative of eutrophic or high trophic level environments. Hajnal and Padisák (2008) used this phytoplankton as indicators of trophic changes in the ecosystem, and verified that cyanobacteria were dominant in low quality waters.

According to Sant'Anna and Azevedo (2000), the most common cyanobacteria genera found in Brazil are Microcystis and Anabaena. However, a number of Cylindrospermopsis species have been reported to dominate reservoirs recently (BOUVY et al., 2000; FIGUEREDO; GIANI, 2009; LOPES et al., 2015). In northeastern Brazil, the genus Planktothrix has been found in the states of Maranhão (NOGUEIRA et al., 2005), Rio Grande do Norte (CÂMARA et al., 2007; CHELLAPPA et al., 2009) and Pernambuco (MOURA et al., 2008). In the state of Pernambuco, 39 reservoirs classified as eutrophic have often demonstrated cyanobacterial blooms of Cylindrospermopsis raciborskii (BOUVY et al., 1999, 2000, 2001), Microcystis aeruginosa (CHELLAPPA; COSTA, 2003) and Anabaena spiroides (MOLICA et al., 2005; LIRA et al., 2011).

Senerpont-Domis (2013) proposed that various climate components correlate to temporal dynamics of natural plankton communities. Annual variability in precipitation can be an important driver of the seasonal dynamics of plankton in tropical systems. Increases in precipitation intensity may redefine the dynamics of plankton communities and favour species adapted to highly variable environments. Senerpont-Domis (2013) also proposed that climate pressures on semi-arid to arid shallow systems are strong and the need for more data on these understudied systems is therefore urgent.

Ceará State shows several conditions that are ideal for the growth of cyanobacteria such as high solar radiation $\left(18 \mathrm{Mj} \cdot \mathrm{m}^{-2} \cdot \mathrm{day}^{-1}\right)$ of approximately 8 hours.day ${ }^{-1}$, short rainy seasons and surface water accumulation in reservoirs with high retention times (FERREIRA, 2008). Furthermore, according to FUNCEME (2016) in the last 55 years, annual mean temperature has increased in approximately $2.7^{\circ} \mathrm{C}$. Monitoring cyanobacteria in reservoirs is an adequate tool to understand the risks involved in using surface water. The study of these organisms' dynamics is critical for decision-making and has a considerable importance in guiding environmental and water resources management plans, as well as new plans of drinking water supply systems.
The increase of filamentous species such as saxitoxin producing Cylindrospermopsis raciborskii has worried water companies in Ceara (LOPES et al., 2015). Although this specie is normally found in tropical zones and has expanded to temperate regions of Europe, North America and South America, no other water company in northeastern Brazil has reported major complications in that regard. Our hypothesis is that the state of Ceara is at the forefront of water quality and cyanobacteria problems and can portray a future scenario to other semi-arid regions. Therefore, the main objective of this investigation was to study the phytoplankton dynamic of two distinct eutrophic artificial reservoirs located in the state of Ceara-Brazil, with emphasis on cyanobacteria and on Cylindrospermopsis sp. and compare their behavior to reservoirs in other semi-arid regions.

\section{MATERIAL AND METHODS}

\section{Study areas}

The catchment of the Sitios Novos (SN) reservoir $\left(03^{\circ} 47^{\prime} 52^{\prime \prime} \mathrm{S}-38^{\circ} 58^{\prime} 12^{\prime \prime} \mathrm{W}\right)$ has an area of $446 \mathrm{~km}^{2}$ and it is located near the west coastal region of Ceara. The region has a avarage rainfall of 1253 mm.year ${ }^{-1}$, concentrated between January and May and an average evaporation rate of 959.5 mm.year ${ }^{-1}$ (COGERH, 2008). The region has a warm, semi-arid, low-latitude climate (As), with a mean annual temperature between 26 and $30{ }^{\circ} \mathrm{C}$. The catchment presents, predominantly, features of the coastal zone with typical mangroves and dense Caatinga biome (COGERH, 2008). SN dam was constructed in 1999 at $50 \mathrm{~m}$ above sea level, has a hydraulic basin area of $20.1 \mathrm{~km}^{2}$ and a storage capacity of $126 \times 10^{6} \mathrm{~m}^{3}$. It provides water for approximately 4,000 inhabitants, its maximum depth is $13 \mathrm{~m}$, and the theoretical residence time is 675 days (COGERH, 2008). During the study period, the reservoir was considered hypertrophic, according to the method used by CETESB (2010), with total phosphorous and Chlorophyll $a$ average concentrations of $263 \pm 80$ and $122 \pm 81 \mu \mathrm{g} \cdot \mathrm{L}^{-1}$, respectively.

Acarape do Meio (AM) reservoir (04¹1'30” S-3848’30” W) was completed in 1924 at $130 \mathrm{~m}$ above sea level. The catchment has an area of $210.0 \mathrm{~km}^{2}$ and the dominant vegetation in the region includes three major formations: Caatinga biome, semi deciduous, and evergreen tropical rain forest. The region has a rainy tropical monsoon climate (Amw'), with a mean annual temperature of $25^{\circ} \mathrm{C}$, lowest temperatures reaching $18^{\circ} \mathrm{C}$, mean annual evaporation of $562 \mathrm{~mm}$ and rainfall of $1051 \mathrm{~mm} /$ year (COGERH, 2008). It is located in a mountainous topography where orographic rainfall rates are irregularly distributed throughout the year. It is inserted in a hydraulic basin with area of $2.2 \mathrm{~km}^{2}$, hosts a population of about 110,000 inhabitants, and has a storage capacity of $31.5 \times 10^{6} \mathrm{~m}^{3}$. It provides water for approximately 15,000 people, its maximum depth is $40 \mathrm{~m}$, and its theoretical residence time is 103 days. The reservoir was considered eutrophic according to the method used by CETESB (2010), with average phosphorous and Chlorophyll $a$ concentrations of $195 \pm 47 \mu$ g.L. $L^{-1}$ and $68 \pm 12 \mu \mathrm{g} \cdot \mathrm{L}^{-1}$, respectively (COGERH, 2008). The location of both reservoirs is shown in Figure 1. 


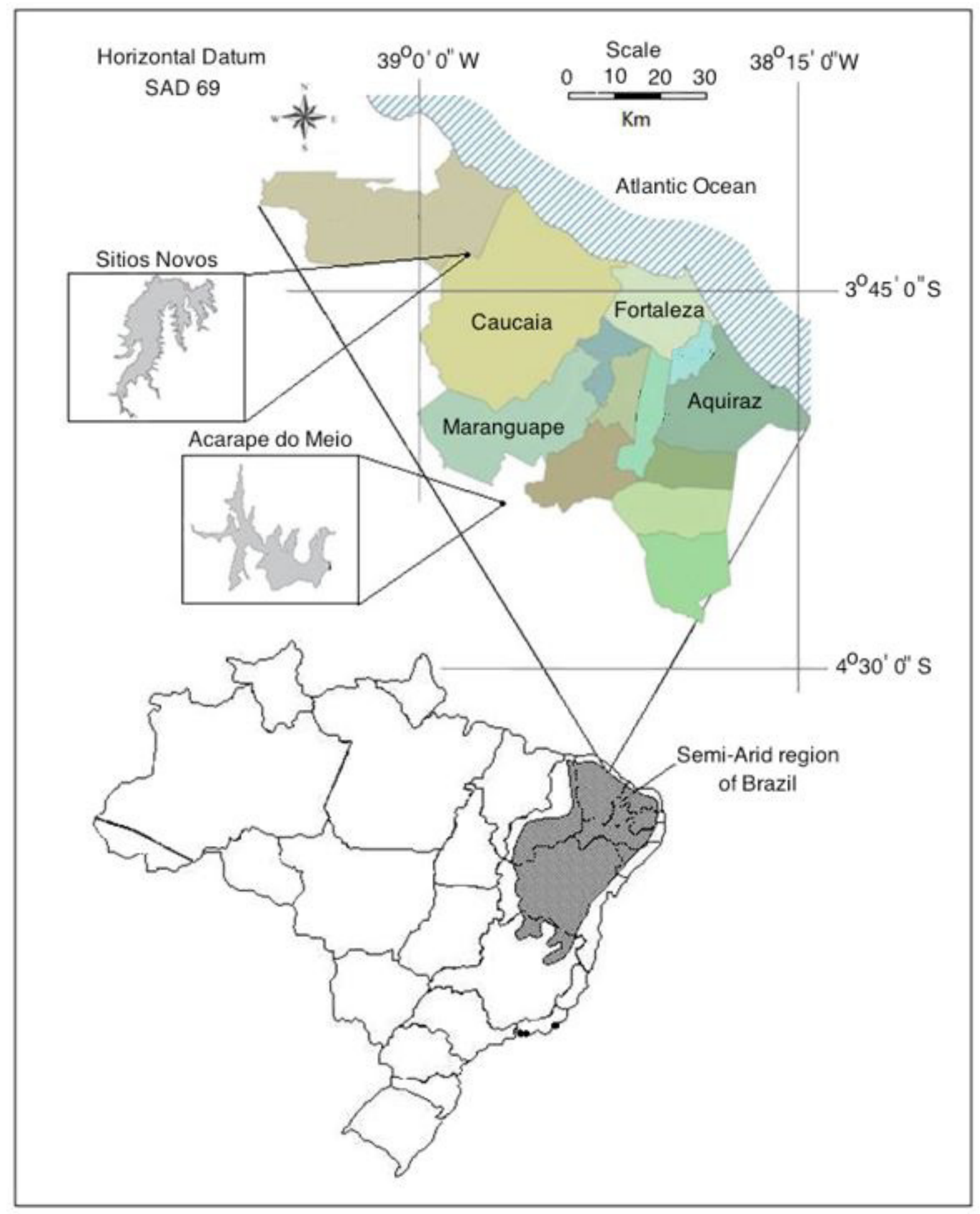

Figure 1. Location of Sítios Novos and Acarape do Meio reservoirs in the semi-arid region of Brazil.

\section{Sampling and analyses}

Counting and classification of phytoplankton was carried out according to APHA (2005), and to comply with the potable water ordinance of the Ministry of Health of Brazil (Ordinance 2914/2011, BRASIL, 2011). Sampling was conducted from January 2010 through July 2011, in two reservoirs: AM and SN (Figure 1). The reservoirs were selected based on two criteria: the recurrence of positive results for saxitoxins (neurotoxin produced by filamentous cyanobacteria), performed by ELISA and confirmed by bioassays in Swiss mice (AOAC, 2003), during 12 month previous to the sampling (Data not shown) and; geographic, micro-climate and other physical differences between the two reservoirs. In order to facilitate data analysis, the studied period was divided into dry period (2010/2), from July through December, and into two wet periods $(2010 / 1 ; 2011 / 1)$, from January through June. 
The dominance and abundance of species were determined based on Lobo and Leighton (1986), where dominant species are those whose densities are higher than $50 \%$ of total density and abundant species are those whose densities that exceed the average density of the populations of each sample. Shannon index (SHANNON; WEAVER, 1949) was used to measure the communities' diversity. In the Shannon index (Equation 1), $\mathrm{p}$ is the proportion $(\mathrm{n} / \mathrm{N})$ of individuals of one particular species found (n) divided by the total number of individuals found $(\mathrm{N})$, and $\mathbf{s}$ is the number of taxa. Data were compared using t-test (paired, two-tailed and one-tailed distribution) and variance was analyzed by using the F-test, both with a significance level of $\mathrm{p}=0.05$.

Samples were collected at the water treatment plant (WTP) intakes at $40 \mathrm{~cm}$ below the water surface, stored in amber glass bottles $(1 \mathrm{~L})$ and preserved with $1.0 \%$ Lugol's iodine. When non-fixed biological material had to be transported, it was kept refrigerated $\left(+4{ }^{\circ} \mathrm{C}\right)$. Cell concentration was carried out by sedimentation of the organisms in a $1 \mathrm{~L}$ measuring cylinder for $24 \mathrm{~h}$. Subsequently, the phytoplankton was counted under an inverted optical microscope (Zeiss Axiovert.A1) using a Sedgewick-Rafter chamber.

$$
H=-\sum_{i=1}^{s} p_{i} \ln p_{i}
$$

Identification of cyanobacteria consisted in grouping them into specific taxonomic categories with the aid of identification keys (KOMÁREK; ANAGNOSTIDIS, 1989, 1998, 2005; ANAGNOSTIDIS; KOMÁREK, 1990). Individuals of the dominant organisms were identified at the lowest taxonomical level possible under an optical microscope at different magnifications, 40 to $100 \mathrm{X}$, depending on the size of the cell or structure analyzed. The characters used in the identification of cyanobacteria were (WERNER, 2002): external morphology; plane of cell division; type of colony; arrangement of cells in the colony; presence or absence of mucilaginous envelope or mucilaginous sheath; shape and dimensions of vegetative cells; structure of trichomes; shape of trichome apex; presence or absence of granules and aerotopes; shape and size of heterocysts; origin and arrangement of akinetes as well as number, size and shape of akinetes.

The results were pooled into three Groups 1 - Cylindrospermopsis sp; Group 2 - other species of cyanobacteria; Group 3 - other components of phytoplankton.
According to Moustaka-Gouni et al. (2009), in the early stages of the life cycle of Cylindrospermopsis sp., no terminal heterocyst is formed, making it difficult to differentiate it from Raphidiopsis sp. In fact, the analysis of partial 16S rRNA gene of the co-existing Cylindrospermopsis and Raphidiopsis morphotypes found in Lake Kastoria, Greece, revealed only one phylotype. The authors proposed that Raphidiopsis represented non-heterocytous stages of Cylindrospermopsis complex life cycle. Wu et al. (2011) and Jiang et al. (2014) also found strong evidence suggesting that Cylindrospermopsis and Raphidiopsis might be congeneric. Therefore, in group Cylindrospermopsis sp. the following species were grouped together: Cylindrospermopsis raciborskii; Cylindrospermopsis catemaco, Cylindrospermopsis phillippinensis and Cylindrospermopsis/Raphidiopsis sp.

Phytoplankton data were examined also considering the rainfall during the study period. Rainfall data was collected at rain gauge stations located in the cities of Caucaia ( $3^{\circ} 47^{\prime} 14^{\prime \prime}$ S- $38^{\circ} 58^{\prime} 59^{\prime \prime}$ W) and Redenção (4'11'42" S-38 48'23" W) close to SN and AM reservoirs, respectively (ANA, 2011).

\section{RESULTS}

In the rainy season of $2010 / 1$, the precipitation was significantly below average rainfall $(\mathrm{p}<0.05)$ while in the rainy season of 2011/1 it was significantly above it in both reservoirs $(p<0.05)$ (Table 1). Figure 2 shows the monthly rain distribution for the two areas during the sampling period. Due to the intense rainy season of 2011 (2011/1), both reservoir reached their maximum capacities and overflowed through their spillway. The same did not happen in the rainy season of 2010 (2010/1).

In $\mathrm{SN}$ reservoir, 41 taxa were identified during the sampling period (Table 2). Four species of Cylindrospermopsis were observed.

Table 1. 30-year average rainfall and actual rainfall in the reservoir's watersheds during the rainy (2010/1 and 2011/1) and dry (2010/2) season.

\begin{tabular}{lcccc}
\hline Reservoir & Date & $\mathbf{2 0 1 0 / 1}$ & $\mathbf{2 0 1 0 / 2}$ & $\mathbf{2 0 1 1 / 1}$ \\
\hline Sitios & AR $(\mathrm{mm})$ & 1252.9 & 114.56 & 1252.9 \\
Novos & $\mathrm{R}(\mathrm{mm})$ & $\mathbf{7 7 8 . 4}$ & 81.6 & 1790.4 \\
\hline Acarape do & AR $(\mathrm{mm})$ & 1051.3 & 101.01 & 1051.3 \\
Meio & $\mathrm{R}(\mathrm{mm})$ & 511.6 & 15.4 & 1211.4 \\
\hline
\end{tabular}

(AR) Avarage Rainfall; (R) Period Rainfall.
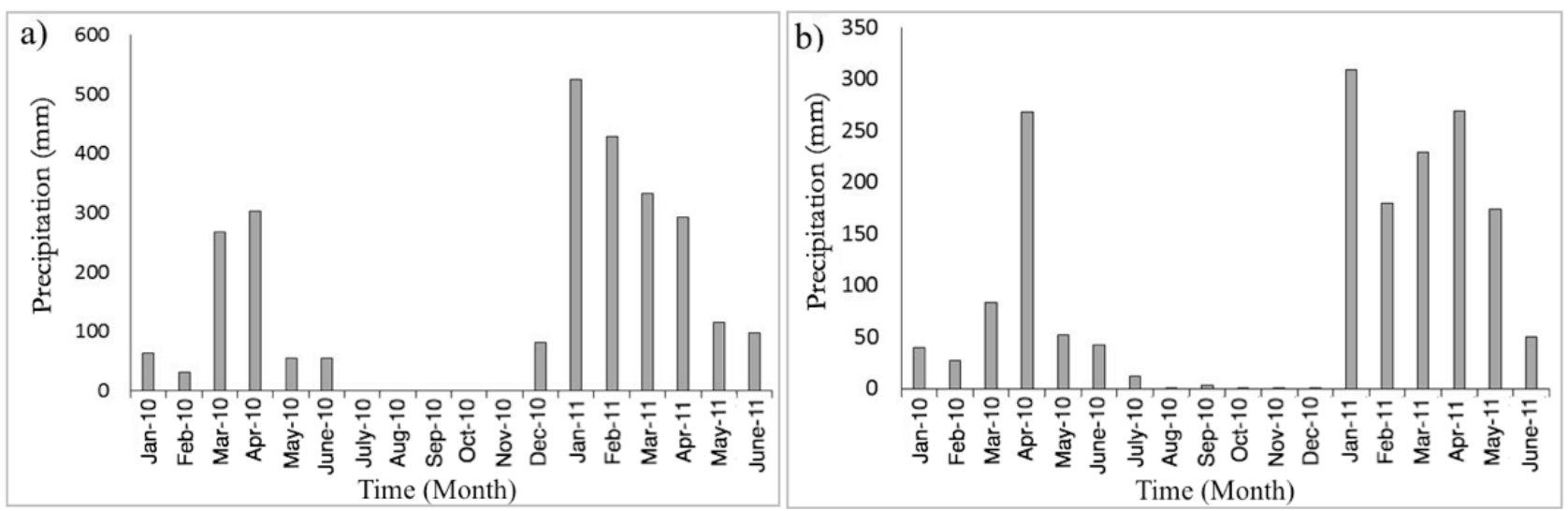

Figure 2. Monthly rain distribution for (a) Sítios Novos and (b) Acarape do Meio reservoirs from Jan/2010 through Jun/2011. 
Table 2. Taxa identified in Sítios Novos and Acarape do Meio reservoirs, their average concentrations and standard deviation from Jan/2010 to Jun/2011.

\begin{tabular}{|c|c|c|c|c|}
\hline \multirow[b]{2}{*}{ Reservoir } & \multicolumn{2}{|c|}{ Sitios Novos } & \multicolumn{2}{|c|}{ Acarape do Meio } \\
\hline & $\begin{array}{c}\text { Avarage } \\
\left(\text { cells. } \mathrm{mL}^{-1}\right)\end{array}$ & $\begin{array}{c}\mathrm{SD} \\
\left(\text { cells.mL } \mathrm{mL}^{-1}\right)\end{array}$ & $\begin{array}{c}\text { Avarage } \\
\left(\text { cells. } \mathrm{mL}^{-1}\right)\end{array}$ & $\begin{array}{c}\mathrm{SD} \\
\left(\text { cells.mL } \mathrm{mL}^{-1}\right)\end{array}$ \\
\hline \multicolumn{5}{|l|}{ Cylindrospermopsis sp. } \\
\hline $\begin{array}{l}\text { Cylindrospermopsis catemaco Komárková-Legnerová \& } \\
\text { R.Tavera }\end{array}$ & $6.12 \mathrm{E}+03$ & $6.08 \mathrm{E}+03$ & $1.32 \mathrm{E}+03$ & $5.84 \mathrm{E}+02$ \\
\hline $\begin{array}{l}\text { Cylindrospermopsis raciborskii (Woloszynska) Seenayya et } \\
\text { Subba Raju }\end{array}$ & $8.21 \mathrm{E}+03$ & $7.56 \mathrm{E}+03$ & $1.83 \mathrm{E}+05$ & $1.54 \mathrm{E}+05$ \\
\hline Cylindrospermopsis phillippinensis (W.R.Taylor) Komárek & $1.62 \mathrm{E}+03$ & $9.27 \mathrm{E}+02$ & $1.11 \mathrm{E}+03$ & $5.63 \mathrm{E}+02$ \\
\hline Cylindrospermopsis/Raphidiopsis sp. & $1.03 \mathrm{E}+04$ & $9.28 \mathrm{E}+03$ & $2.67 \mathrm{E}+05$ & $1.44 \mathrm{E}+05$ \\
\hline \multicolumn{5}{|l|}{ Other cyanobacteria } \\
\hline Anabaenal Aphanizomenon sp. & $1.66 \mathrm{E}+03$ & $1.07 \mathrm{E}+03$ & - & - \\
\hline Anabaena sp. & $2.71 \mathrm{E}+03$ & $2.68 \mathrm{E}+03$ & - & - \\
\hline Aphanizomenon sp. & $2.35 \mathrm{E}+03$ & $2.03 \mathrm{E}+03$ & - & - \\
\hline Chroococcales & $3.84 \mathrm{E}+04$ & $3.93 \mathrm{E}+04$ & $7.10 \mathrm{E}+02$ & $6.48 \mathrm{E}+02$ \\
\hline Chroococcus sp. & $4.15 \mathrm{E}+03$ & $4.17 \mathrm{E}+03$ & $9.23 \mathrm{E}+01$ & $8.58 \mathrm{E}+01$ \\
\hline Coelomoron sp. & $2.14 \mathrm{E}+03$ & - & - & - \\
\hline Geitlerinema sp. & $4.06 \mathrm{E}+03$ & $3.59 \mathrm{E}+03$ & $1.70 \mathrm{E}+03$ & $1.54 \mathrm{E}+03$ \\
\hline Lynbya sp. & $2.22 \mathrm{E}+02$ & $1.44 \mathrm{E}+02$ & - & - \\
\hline Merismopedia sp. & $1.51 \mathrm{E}+04$ & $2.51 \mathrm{E}+04$ & $2.51 \mathrm{E}+04$ & $4.82 \mathrm{E}+04$ \\
\hline Microcystis aeruginosa (Kützing) Kützing & $1.44 \mathrm{E}+05$ & - & - & - \\
\hline Planktolyngbia sp. & $6.80 \mathrm{E}+02$ & & $1.24 \mathrm{E}+03$ & $1.14 \mathrm{E}+03$ \\
\hline Planktothrix agardhii (Gomont) Anagnostidis \& Komárek & $1.41 \mathrm{E}+05$ & $1.10 \mathrm{E}+05$ & $7.98 \mathrm{E}+03$ & $2.55 \mathrm{E}+03$ \\
\hline Pseudanabaena sp & $1.88 \mathrm{E}+03$ & $1.50 \mathrm{E}+03$ & $3.20 \mathrm{E}+04$ & $2.72 \mathrm{E}+04$ \\
\hline Oscillatoriales & $5.34 \mathrm{E}+03$ & - & - & - \\
\hline \multicolumn{5}{|l|}{ Other groups } \\
\hline Actinastrum sp. & $3.43 \mathrm{E}+02$ & $3.97 \mathrm{E}+02$ & - & - \\
\hline Actinochloris sphaerica Korschikov & $1.32 \mathrm{E}+02$ & - & - & - \\
\hline Aulacoseira sp. & $8.42 \mathrm{E}+01$ & $2.00 \mathrm{E}+01$ & - & - \\
\hline Ankyra sp. & $6.00 \mathrm{E}+00$ & - & - & - \\
\hline Aulacoseira granulata (Ehrenberg) Simonsen & $3.35 \mathrm{E}+02$ & $2.68 \mathrm{E}+02$ & - & - \\
\hline Bacillariophyta & $2.77 \mathrm{E}+02$ & $3.36 \mathrm{E}+02$ & $1.63 \mathrm{E}+03$ & $1.66 \mathrm{E}+03$ \\
\hline Botryococcus sp. & $1.22 \mathrm{E}+03$ & - & - & - \\
\hline Chlorococcales & $1.34 \mathrm{E}+02$ & $1.53 \mathrm{E}+02$ & - & - \\
\hline Closterium sp. & $8.12 \mathrm{E}+01$ & $6.48 \mathrm{E}+01$ & $8.38 \mathrm{E}+01$ & $6.00 \mathrm{E}+01$ \\
\hline Coelastrum sp. & $2.10 \mathrm{E}+02$ & $2.11 \mathrm{E}+02$ & - & - \\
\hline Crucigeniella sp. & - & - & $5.20 \mathrm{E}+02$ & $3.22 \mathrm{E}+02$ \\
\hline Crucigenia sp. & $5.79 \mathrm{E}+02$ & - & $3.20 \mathrm{E}+02$ & $1.29 \mathrm{E}+02$ \\
\hline Cyclotella sp. & $1.21 \mathrm{E}+02$ & $9.80 \mathrm{E}+01$ & $3.60 \mathrm{E}+02$ & $4.12 \mathrm{E}+02$ \\
\hline Cosmarium sp. & & & $4.05 \mathrm{E}+01$ & $5.53 \mathrm{E}+01$ \\
\hline Cryptomonas sp. & $8.52 \mathrm{E}+01$ & $9.75 \mathrm{E}+01$ & $5.03 \mathrm{E}+02$ & $5.52 \mathrm{E}+02$ \\
\hline Desmidiaceae & $1.10 \mathrm{E}+02$ & - & - & - \\
\hline Dictyosphaerium sp. & $1.34 \mathrm{E}+03$ & $1.25 \mathrm{E}+03$ & - & - \\
\hline Desmodesmus sp. & $5.38 \mathrm{E}+02$ & - & - & - \\
\hline Micractinium sp. & $3.48 \mathrm{E}+02$ & $2.51 \mathrm{E}+02$ & - & - \\
\hline Monoraphidium contortum (Thuret) Komárková-Legnerová & $1.95 \mathrm{E}+02$ & $2.10 \mathrm{E}+02$ & $3.28 \mathrm{E}+02$ & $6.33 \mathrm{E}+02$ \\
\hline Oocystis sp. & $1.77 \mathrm{E}+02$ & - & - & - \\
\hline Peridinium sp. & - & - & $1.14 \mathrm{E}+02$ & $6.35 \mathrm{E}+01$ \\
\hline Scenedesmus sp. & $4.27 \mathrm{E}+02$ & $4.93 \mathrm{E}+02$ & $1.13 \mathrm{E}+02$ & $1.51 \mathrm{E}+02$ \\
\hline Staurastrum sp. & $9.41 \mathrm{E}+01$ & $5.33 \mathrm{E}+01$ & $7.95 \mathrm{E}+01$ & $6.61 \mathrm{E}+01$ \\
\hline Tetraedron sp. & - & - & $8.56 \mathrm{E}+01$ & $5.97 \mathrm{E}+01$ \\
\hline Tetraedron minimum (A.Braun) Hansgirg & - & - & $2.27 \mathrm{E}+02$ & $2.15 \mathrm{E}+02$ \\
\hline Trachelomonas sp. & $6.73 \mathrm{E}+01$ & $8.15 \mathrm{E}+01$ & $9.05 \mathrm{E}+01$ & $9.18 \mathrm{E}+01$ \\
\hline
\end{tabular}


Cylindrospermopsis raciborskii was the most frequent specie and the taxa Cylindrospermopsis/Raphidiopsis sp. was the most abundant. In Group 2, with 15 taxa, Plank:tothrix agardhii was dominant during most part of the sampling period (Figure 3), and the order Chroococcales was the most frequent, showing co-dominance. The genus Merismopedia $s p$. was also abundant in this group and Microcystis aeruginosa was identified in only one sample (September 2010) in a concentration of $1.44 \times 10^{5}$ cells. $\mathrm{mL}^{-1}$. Group 3 presented the most richness with 22 taxa. Chlorophyceae was the most represented class followed by Bacillariophyceae. Aulacoseira granulata was the most frequent specie and the genus Dictyosphaerium sp. the most abundant in this group. Concentration of Group 3 was very low, in average 2.1\%, having its greater contribution on February 2011. There were no significant variations $(p<0.05)$ in richness within the same group between raining and dry periods except for Group 2, where the richness was greater in the rainy season of 2011.

In the AM reservoir, 26 taxa were identified (Table 2), of which four taxa were from Group 1, eight taxa of Group 2, and 14 taxa of Group 3. Cylindrospermopsis raciborskii and Cylindrospermopsis / Raphidiopsis sp. were the most frequent and dominant taxa among all the phytoplankton community until March 2011 when it was substituted by members of Group 2 (Figure 2). In Group 2, Merismopedia sp. and Pseudanabaena sp were the most abundant and frequent genera, while the other Chroococcales and Planktothrix agardhii had smaller representation, differently from what was
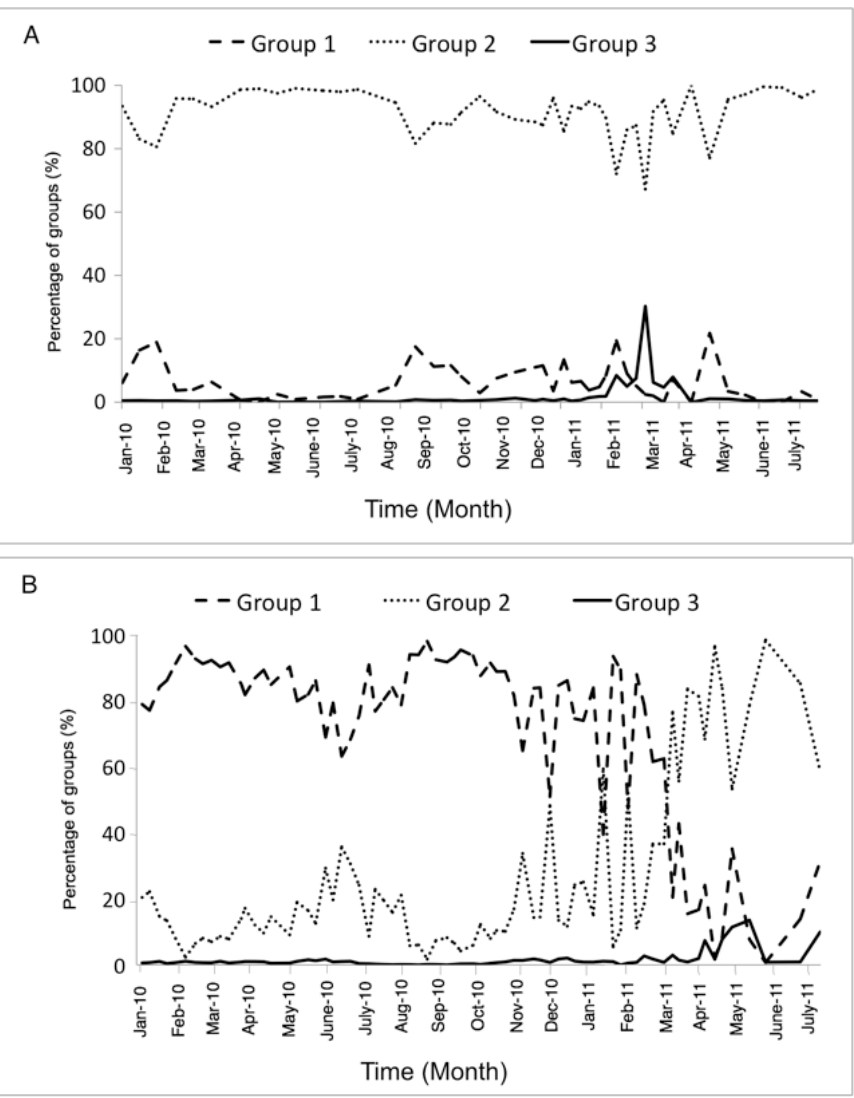

Figure 3. Percentage of Group 1 (Cylindrospermopsis sp.), Group 2 (Other cyanobacteria) and Group 3 (Other groups) in (A) Sítios Novos and (B) Acarape do Meio reservoirs from Jan/2010 through Jun/2011. observed in SN reservoir. Merismopedia sp. and Pseudanabaena sp were respectively the dominant and co-dominant genera after March 2011. Group 3 presented again the most richness, presenting bacillariophyceae as the most representative and frequent class followed by chlorophyceae. Crucigeniella sp. and Cryptomonas sp. were the most abundant genera in this group. Similar to the behaviour of SN reservoir, no significant variations $(\mathrm{p}<0.05)$ was observed in richness within the groups between periods, except for Group 2 where the richness was greater in 2011/1 as compared to 2010/1. The percentage concentration (Figure 3 ) of Other groups was, like in Sítios Novos reservoir, very low (average $0.9 \%$ ) and its greater contribution occurred on May 2011 (13.6\%).

When comparing the percentage contributions of Group 1 and Group 2 (Figure 3) for both reservoirs, an interesting trend was identified. A close inverse correlation was found with high correlation coefficients for $\mathrm{SN}\left(\mathrm{R}^{2}=-0.862\right)$ and for $\mathrm{AM}\left(\mathrm{R}^{2}=-0.997\right)$ reservoirs meaning that when Cylindrospermopsis sp dominated, it hampered the growth of other cyanobacteria or vice-versa. No close correlations were found between Cylindrospermopsis sp. or between other cyanobacteria and Group 3.

The Phytoplankton concentrations (Figure 4) in SN and AM, showed the following trend $(\mathrm{p}<0.05)$ :

- Group 1 (2010/2>2010/1=2011/1) and (2010/1=2010/2>2011/1);
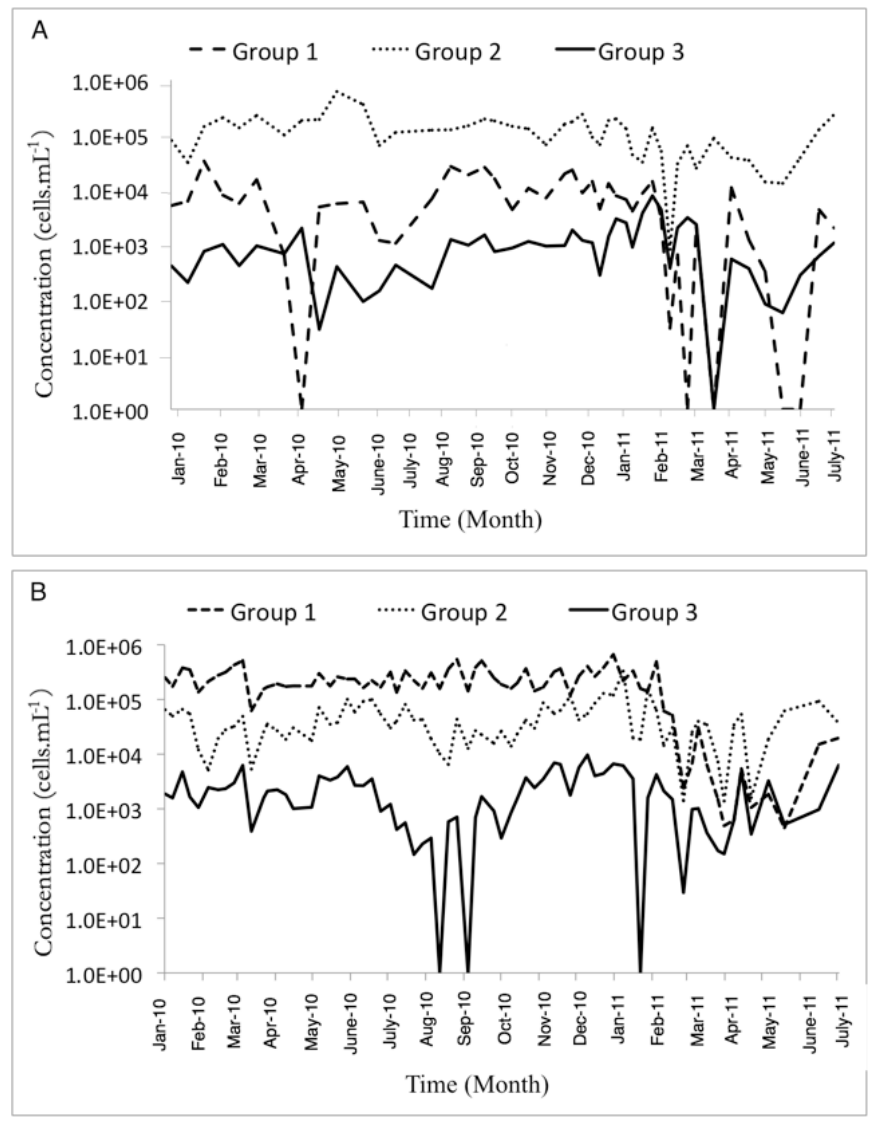

Figure 4. Concentration (cells.mL $\mathrm{m}^{-1}$ ) of Group 1 (Cylindrospermopsis sp.), Group 2 (Other cyanobacteria) and Group 3 (Other groups) in (a) Sítios Novos and (b) Acarape do Meio reservoirs from Jan/2010 through Jun/2011. 
- Group $2(2010 / 1=2010 / 2>2011 / 1)$ and $(2010 / 1=2010 / 2=2011 / 1)$;

- Group $3(2010 / 1=2010 / 2<2011 / 1)$ and $(2010 / 1=2010 / 2=2011 / 1)$.

In other words, the average concentration of Cylindrospermopsis sp. was significantly smaller $(p<0.05)$ in the rainy season of 2011 than in 2010 in both reservoirs; the average concentration of Group 3 was significantly higher $(p<0.05)$ in the rainy season of 2011 in SN reservoir and; the average concentration of Group 2 and Group 3 in AM reservoir did not change significantly $(p<0.05)$ during the study period. The concentration variances of all groups in both reservoirs, verified by F-test, were significantly greater $(p<0.05)$ in the rainy season of 2011 than in 2010.

Species diversity has been used as a measure of community stability in which low or changing diversity may indicate a stressed or unstable environment. In this context, the diversity in SN (1.08) was higher than that AM reservoir (0.60) (Figure 5). The average Shannon index in both reservoirs showed the following trend: Group $2>$ Group $1>$ Group 3. Although Group 3 showed a very low diversity, it was significantly higher $(\mathrm{p}<0.05)$ during 2011/1 than in 2010 in both reservoirs. Cylindrospermopsis sp., other cyanobacteria and other groups diversity index had a significantly higher variance $(\mathrm{p}<0.05)$ in $\mathrm{SN}$ than in AM reservoir.

\section{DISCUSSION}

In the $\mathrm{SN}$ and $\mathrm{AM}$ reservoirs cyanophyta represented $45 \%$ and $43 \%$ and clorophyta $33 \%$ and $30 \%$ of phytoplankton taxa number, respectively. On the other hand in Jucazinho reservoir, the phytoplankton was composed of chlorophyta with $45 \%$ and cyanophyta with 30\% (MOURA et al., 2012). Higher richness of chlorophyta, as compared to cyanophyta, was also observed in Botafogo (LIRA et al., 2009), Pedra and Funil (MOURA et al., 2013) reservoirs. Although Jucazinho, Botafogo, Pedra and Funil are located in the same northeastern region of Brazil and judging by the dominance of cyanophyta, it appears that the water qualities in $\mathrm{SN}$ and $\mathrm{AM}$ are inferior to the waters in the previously mentioned reservoirs, indicating that this region is not homogeneous when it comes to phytoplankton dynamics. In fact, droughts appear to

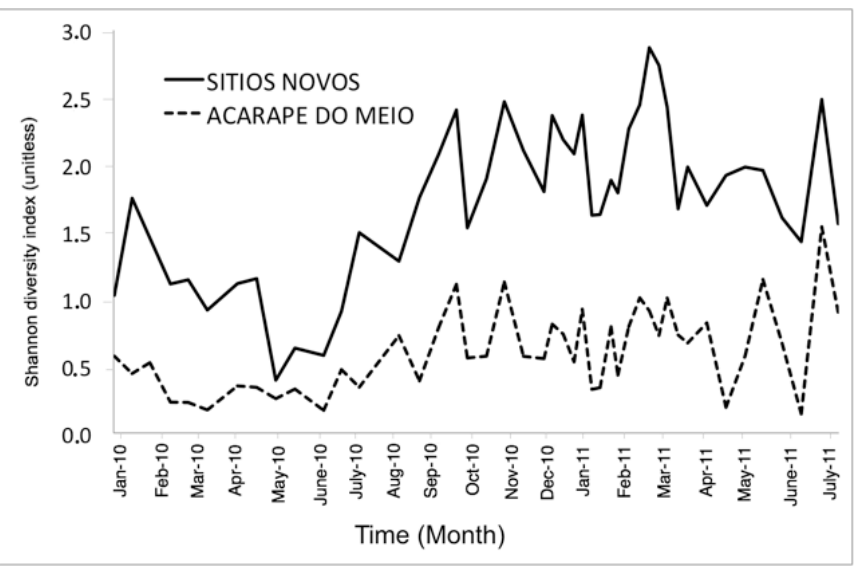

Figure 5. Shannon Diversity index in Sítios Novos and Acarape do Meio reservoirs from Jan/2010 through Jun/2011. be increasing in intensity and duration, especially in the state of Ceará (IPCC, 2007) and, according to FUNCEME (2016), the average annual temperature in Ceara has increased $2.7^{\circ} \mathrm{C}$ in the last 55 years. Since, Cylindrospermopsis raciborskii displays a positive net growth from $20^{\circ}$ to $35^{\circ} \mathrm{C}$, with maximum rate at about $30{ }^{\circ} \mathrm{C}$ (SAKER; GRIFFITHS, 2000; O’NEIL et al., 2012), this temperature increase may explain the capability of this cyanophyta to thrive in there.

In Kusalla reservoir, located in the savannah zone of Nigeria, chlorophyta was the dominant taxa with $36 \%$, followed by the cyanophyta (30\%) (KUTAMA et al., 2014). Zempoala, Zirahuen, Lago de Guadalupe and Valle de Bravo reservoirs, in Mexico, also demonstrated a lower richness of cyanophyta (>13\%) compared to chlorophyta and Bacillariophyta. These results suggest that in the semi-arid region of Ceara, phytoplankton richness is relatively low and highly dominated by cyanobacteria, with special emphasis to the filamentous Plank.tothrix agardhi. and Cylindrospermopsis sp., as compared to other reservoirs in other and in the same semi-arid region, indicating a very specific and adverse peculiarity of this micro region.

In AM reservoir, Cylindrospermopsis sp. dominated during 2010 rainy and dry season but was substituted by Group 2, especially Merismopedia sp. and Pseudanabaena sp in rainy season of 2011, when the reservoir overflowed through its spillway. In SN reservoir, Planktothrix agardhii was dominant during most of the sampling period but had very small representation in AM reservoir. Moura et al. (2013) also found that Planktothrix agardbii was dominant in Funil reservoir during the rainy season, overwhelming the concentration of Cylindrospermopsis raciborskii. This may have serious implications for drinking water reservoirs.

A significantly higher diversity variation of all phytoplankton groups was observed in $\mathrm{SN}$ as compared to AM. The average concentration of Group 2 and Group 3 did not significantly change in the AM reservoir during the sampling period as it did in SN. This "higher stability" shown by AM reservoir is probably due to its greater depth, lower water temperatures and less exposure to wind, leading to a more stable stratification. This stability could also be observed in Chlorophyll $a$ low variability. While the coefficient of variation of Chlorophyll $a$ was $85 \%$ in SN, in AM it did not reach $22 \%$. Similarly, the phytoplankton dynamic of two eutrophic reservoirs in the semi-arid region of Pernambuco was influenced by the thermal pattern. While stratification determined the dominance and high biomass of Cylindrospermopsis raciborskii, destratification favoured competition among species (DANTAS et al., 2011).

The very low Shannon indices $(\mathrm{SN}=1.08$ and $\mathrm{AM}=0.60)$ found, indicate that eutrophication has a high negative impact on phytoplankton diversity in both reservoirs. Group 3 was significantly more diverse in the rainy season of 2011 when precipitation was higher than average. Kutama et al. (2014) suggested that in Kusalla reservoir, located in the savanna zone of Nigeria, Shannon indices of 2.11 and 1.81 indicated, already, lower species diversity and high impact of pollution on water quality. In Jucazinho reservoir, Moura et al. (2012) found a low diversity (2.38) and that species dominance was significantly different between rainy and dry season.

Also during the rainy season of 2011, lower average concentration of Cylindrospermopsis sp. was measured, while the average concentration, diversity and richness of Group 3 increased 
in both reservoirs. Deletic and Maksimovic (1998) and Jones and Sauter (2005) suggested that the decrease in the concentration of cyanobacteria after a rainfall event could be explained by the increase in turbidity due to dissolved organic carbon and suspended sediments. Filamentous species are not favoured by high turbidity, which inhibit access to light and nutrients in the water column (DUNCK et al., 2013). Another plausible explanation for that decrease was proposed by Bouvy et al. (2001). According to that study, high rainfall events could lead to reduced phytoplankton concentration due to the higher flushing and diluting rates of water in the reservoir. In fact, this explanation appears to be more plausible for this case study since in the rainy season of 2010 no significant variation in the phytoplankton was observed.

Percentage contribution between Cylindrospermopsis sp. and other cyanobacteria showed a very close inverse relationship in both reservoirs. Cylindrospermopsis raciborskii can either dominate or be displaced by Microcystis aeruginosa when exposed to different conditions (MARINHO et al., 2013). Under light and phosphate limitation, competition led the strongest Cylindrospermopsis raciborskii strain to dominate. On the other hand, the strongest Microcystis aeruginosa strain displaced Cylindrospermopsis raciborskii in the same limiting condition. In the first case both strains co-existed in equilibrium but in the second, the system did not reach equilibrium and both strains were washed out.

Ammar et al. (2014) investigated the growth of Cylindrospermopsis raciborskii and Planktothrix agardhii when exposed to a range of light and nutrient conditions. No significant allelopathic effect was observed, although significantly lower growth rates were observed in mixed cultures, reflecting other interactions. Planktothrix agardhii grew faster with low light intensity and high nutrient concentrations, but was drastically inhibited by nitrogen deprivation. In contrast, Cylindrospermopsis raciborskii outgrew Planktothrix agardhii at higher $\mathrm{NH}_{4}{ }^{+}$concentrations. Bittencourt-Oliveira et al. (2012) found that in Arcoverde reservoir, the populations of Planktothrix agardhii and Cylindrospermopsis raciborskii were negatively related, with the species prevalence depending on the seasonal periods.

\section{CONCLUSIONS}

The results suggest that in the tropical semi-arid Ceara, the composition and dynamic of phytoplankton has a distinct trend, differing from other areas in that same semi-arid region of Brazil, as reported so far. Phytoplankton richness is low and highly dependent on cyanobacteria, with special emphasis to the filamentous Planktothrix agardhi and Cylindrospermopsis sp. The very low Shannon indices indicate that eutrophication has a strong negative impact in phytoplankton diversity on both reservoirs. The combination of these findings point to an extremely low water quality and brings enormous challenges to the drinking water industry and to the state economy.

This research also presents real scale evidence that the presence of Cylindrospermopsis raciborskii has an inverse relation to other cyanobacteria, corroborating to findings in controlled experiments reported in the literature.

Another important point illustrated here is that rainfall was an important driver for phytoplankton dynamics when analysed in conjunction with other reservoir characteristics such as detention time. Major changes in the phytoplankton dynamics were only observed during the rainy season of 2011. A few of them were:

- Change in the dominant group in AM reservoir from Cylindrospermopsis sp. to other cyanobacteria, especially Merismopedia sp. and Pseudanabaena sp;

- Higher diversity and richness of Group 3 in both reservoir and;

- Lower average concentration of Cylindrospermopsis sp. and higher average concentration of Group 3 in both reservoir.

The explanation that the main cause for the decrease in concentration of cyanobacteria after a rainfall event could be an increase in turbidity due to run-off, dissolved organic carbon or resuspension of sediments was though improbable since this phenomenon must also have occurred in the rainy season of 2010 and displayed no significant impact to phytoplankton dynamic. Rather, it is suggested that high rainfall season could lead to reduced cyanobacteria concentrations due to the higher flushing rates and water dilution caused by the reservoirs overflow. However, this hypothesis still needs to be verified in future research.

\section{ACKNOWLEDGEMENTS}

We thank FINEP and CNPq for the support and CAGECE (Water and Wastewater Company of Ceará) for kindly making available their staff, facilities, and important data to the development of this study. We also thank Dr. Carlos Pestana of the South Australian Water Corp. for proof reading this paper.

\section{REFERENCES}

AMMAR, M.; COMTE, K.; TRAN, T. D. C.; BOUR, M. Initial growth phases of two bloom-forming cyanobacteria (Cylindrospermopsis raciborskii and Planktothrix agardbii) in monocultures and mixed cultures depending on light and nutrient conditions. Annales de Limnologie: International Journal of Limnology, v. 50, n. 3, p. 231 240, 2014. http://dx.doi.org/10.1051/limn/2014096.

ANA - AGÊNCIA NACIONAL DAS ÁGUAS. Portal da qualidade das águas. Brasília: ANA, 2011. Available in: <http://pnqa.ana.gov. $\mathrm{br} /$ IndicadoresQA/introdu $\% \mathrm{C} 3 \% \mathrm{~A} 7 \% \mathrm{C} 3 \% \mathrm{~A} 3$ o.aspx $>$. Access in: 29 fev. 2012.

ANAGNOSTIDIS, K.; KOMÁREK, J. Modern approach to the classification system of cyanophytes 5 - Stigonematales. Algological Studies, Stuttgart, v. 79, p. 1-73, 1990.

AOAC - ASSOCIATION OF OFFICIAL ANALYTICAL CHEMISTS. Paralytic shellfish poison. In: HORWITZ, W. (Ed.). Official Methods of Analysis of AOAC International. 17th ed. Gaithersburg: AOAC International, 2003. vol. 2, chap. 49, p. 59-91.

APHA - AMERICAN PUBLIC HEALTH ASSOCIATION. Standard methods for the examination of water and wastewater. 21st ed. Washington, DC: American Public Health Association, 2005. 
BITTENCOURT-OLIVEIRA, M. C.; DIAS, S. N.; MOURA, A. N.; CORDEIRO-ARAÚJO, M. K.; DANTAS, E. W. Seasonal dynamics of cyanobacteria in a eutrophic reservoir (Arcoverde) in a semi-arid region of Brazil. Brazilian Journal of Biology $=$ Revista Brasileira de Biologia, v. 72, n. 3, p. 533-544, 2012. PMid:22990824. http://dx.doi.org/10.1590/S1519-69842012000300016.

BOUVY, M.; FALCAO, D.; MARINHO, M.; PAGANO, M.; MOURA, A. Occurrence of Cylindrospermopsis (Cyanobacteria) in 39 Brazilian tropical reservoirs during the 1998 drought. Aquatic Microbial Ecology, v. 23, n. 1, p. 13-27, 2000. http://dx.doi. org/10.3354/ame023013.

BOUVY, M.; MOLICA, R.; OLIVEIRA, S.; MARINHO, M.; BEKER, B. Dynamics of a toxic cyanobacterial bloom (Cylindrospermopsis raciborskii) in a shallow reservoir in the semi-arid region of northeast Brazil. Aquatic Microbial Ecology, v. 20, p. 285-297, 1999. http:// dx.doi.org/10.3354/ame020285.

BOUVY, M.; MOLICA, R.; OLIVEIRA, S.; MARINHO, M.; BEKER, B. Effects of a cyanobacterial bloom (Cylindrospermopsisraciborskii) on bacterial and zooplankton communities in Ingazeira reservoir (Northeast, Brazil). Aquatic Microbial Ecology, v. 25, p. 215-227, 2001. http://dx.doi.org/10.3354/ame025215.

BRASIL. Ministério da Saúde. Portaria no 2.914, de 12 de dezembro de 2011. Dispõe sobre os procedimentos de controle e de vigilância da qualidade da água para consumo humano e seu padrão de potabilidade. Diário Oficial [da] República Federativa do Brasil, Brasília, DF, 2011.

CÂMARA, F. R. A.; LIMA, A. K. A.; CHELLAPA, N. T. Diversidade da comunidade fitoplanctônica do Canal do Pataxó, Rio Grande do Norte. Revista Brasileira de Biociências, v. 5, n. 2, p. 21-23, 2007.

CETESB - COMPANHIA AMBIENTAL DO ESTADO DE SÃO PAULO. Secretaria de Meio Ambiente do Estado de São Paulo. Índice de Estado Trófico - IET. São Paulo, 2010. Available from: <http://www.cetesb.sp.gov.br>. Access in: 06 out. 2014.

CHELLAPPA, N. T.; CAMARA, F. R. A.; ROCHA, O. Phytoplankton community: indicator of water quality in the Armando Ribeiro Gonçalves Reservoir and Pataxó Channel, Rio Grande do Norte, Brazil. Brazilian Journal of Biology $=$ Revista Brasileira de Biologia, v. 69, n. 2, p. 241-251, 2009. PMid:19675924. http://dx.doi.org/10.1590/ S1519-69842009000200003.

CHELLAPPA, N. T.; COSTA, M. A. M. Dominant and co-existing species of cyanobacteria from a eutrophicated reservoir of Rio Grande do Norte State, Brazil. Brazil Acta Oecologica, v. 24, p. 3-10, 2003. http://dx.doi.org/10.1016/S1146-609X(03)00005-5.

COGERH - COMPANHIA DE GESTÃO DOS RECURSOS HÍDRICOS. Rede de monitoramento da qualidade de água. Fortaleza: Governo do Estado do Ceará, 2008.

DANTAS, E. W.; MOURA, A. N.; BITTENCOURT-OLIVEIRA, M. C. Cyanobacterial blooms in stratified and destratified eutrophic reservoirs in semi-arid region of Brazil. Anais da Academia Brasileira de Ciencias, v. 83, n. 4, p. 1327-1338, 2011. PMid:22146960. http:// dx.doi.org/10.1590/S0001-37652011000400019.

DELETIC, A. B.; MAKSIMOVIC, C. T. Evaluation of water quality factors in storm runoff from paved áreas. Journal of Environmental Engineering, v. 124, n. 9, p. 869-879, 1998. http:// dx.doi.org/10.1061/(ASCE)0733-9372(1998)124:9(869).

DUNCK, B.; BORTOLINI, J. C.; RODRIGUES, L.; RODRIGUES, L. C.; JATI, S.; TRAIN, S. Functional diversity and adaptative strategies of planktonic and periphytic algae in isolated tropical floodplain lake. Brazilian Journal of Botany, v. 3, n. 4, p. 257-266, 2013. http:/ /dx.doi.org/10.1007/s40415-013-0029-y.

FERREIRA, A. C. S. Leitura de minuto: cianobactérias. Fortaleza: COGERH, 2008. vol. 10.

FIGUEREDO, C. C.; GIANI, A. Phytoplankton community in tropical lake of Lagoa Santa (Brazil): conditions favouring a persistent bloom of Cylindrospermopsis raciborskii. Limnologica and Ecology and Management of Inland Waters, v. 39, n. 4, p. 264-272, 2009. http://dx.doi.org/10.1016/j.limno.2009.06.009.

FUNCEME - FUNDAÇÃO CEARENCE DE METEOROGIA E RECURSOS HIDRICOS. Internal report from historical temperature data. Fortaleza: FUNCEME, 2016. Available from: < http://www. funceme.br/\#site>. Access on: 06 jun. 2016.

GOWEN, R. J.; TETT, P.; BRESNAN, E.; DAVIDSON, K.; MCKINNE, A.; HARRISON, P. J.; MILLIGAN, S.; MILLS, D. K.; SILKE, J.; CROOKS, A. Anthropogenic nutrient enrichment and blooms of harmful phytoplankton. Oceanography and Marine Biology, v. 50, p. 65-126, 2012.

HAJNAL, E.; PADISÁK, J. Analysis of long-term ecological status of Lake Balaton based on the ALMOBAL phytoplankton database. Hydrobiologia, v. 599, n. 1, p. 227-237, 2008. http:/ /dx.doi. org/10.1007/s10750-007-9207-x.

IPCC - INTERGOVERNMENTAL PANEL ON CLIMATE CHANGE. Working Group III Report. climate change 2007. New York: United Nations Environmental Programme, 2007.

JIANG, Y.; XIAO, P.; YU, G.; SHAO, J.; LIU, D.; AZEVEDO, S. M. F. O.; LI, R. Sporadic distribution and distinctive variations of cylindrospermopsin genes in cyanobacterial strains and environmental samples from Chinese freshwater bodies. Applied and Environmental Microbiology, v. 80, n. 17, p. 5219-5230, 2014. PMid:24928879. http://dx.doi.org/10.1128/AEM.00551-14.

JONES, W. W.; SAUTER, S. Distribution and abundance of Cylindrospermopsis raciborskii in Indiana Lakes and Reservoirs. Bloomington: School of Public and Environmental Affairs, Indiana University, 2005. 54 p.

KOMÁREK, J.; ANAGNOSTIDIS, K. Modern approach to the classification system of cyanophytes: 4-Nostocales. Archives fur Hydrobiologie Supplementband, v. 82, n. 3, p. 247-345, 1989. 
KOMÁREK, J.; ANAGNOSTIDIS, K. Modern approach to the classification system of cyanophytes Cyanoprokaryota: Chroococcales. In: ETTL, H.; GÄRTNER, G.; HEYNIG, H.; MOLLENHAUER, D. (Ed.). Süsswasserflora von Mitteleuropa. Berlin: Gustav Fischer, 1998. v. 19, pt. 1.

KOMÁREK, J.; ANAGNOSTIDIS, K. Modern approach to the classification system of cyanophytes Cyanoprokariota: Oscillatoriales. In: ETTL, H.; GÄRTNER, G.; HEYNIG, H.; MOLLENHAUER, D. (Ed.). Süsswasserflora von Mitteleuropa. Heidelberg: Elsevier/Spectrum, 2005. v. 19, pt. 2.

KUTAMA, R. M.; ABUBAKAR, M. M.; BALARABE, M. L. The Plankton as Indicators of water quality in Kusalla Reservoir: a shallow man made lake. IOSR Journal of Pharmacy and Biological Sciences, v. 9, n. 3, p. 12-15, 2014. http://dx.doi.org/10.9790/300809311215.

LIRA, G. A. S. T.; BITTENCOURT-OLIVEIRA, M. C.; MOURA, A. N. Structure and Dynamics of Phytoplankton Community in the Botafogo Reservoir-Pernambuco-Brazil. Brazilian Archives of Biology and Technology, v. 52, n. 2, p. 493-501, 2009. http:/ /dx.doi. org/10.1590/S1516-89132009000200029.

LIRA, G. A.; ARAUJO, E. L.; BITTENCOURT-OLIVEIRA, M. C.; MOURA, A. N. Phytoplankton abundance, dominance and coexistence in an eutrophic reservoir in the state of Pernambuco, Northeast Brazil. Anais da Academia Brasileira de Ciencias, v. 83, n. 4, p. 13-26, 2011. PMid:22146959. http://dx.doi.org/10.1590/ S0001-37652011000400018.

LOBO, E.; LEIGHTON, G. Estructuras comunitarias de las fitocenosis plancto'nicas de los sistemas de desembocaduras de rios y esteros de la zona central de Chile. Revista de Biologia Marina, v. 22, p. 1-29, 1986.

LOPES, I. K. L.; BARROS, M. U. G.; PESTANA, C. J.; CAPELO NETO, J. Prevalence of Paralytic Selfish Poison-producing Planktothrix agardhii and Cylindrospermopsis raciborskii in a brazilian semiarid reservoir. Acta Limnologica Brasiliensia, v. 27, n. 2, p. 238-246, 2015. http://dx.doi.org/10.1590/S2179-975X5014.

MARINHO, M.M., SOUZA, M.B.G., LÜRLING, M. Light and phosphate competition between Cylindrospermopsis raciborskii and Microcystis aeruginosa is strain dependent. Microbiology of Aquatic Systems, v. 66, p. 479-488, 2013.

MOLICA, R. J. R.; OLIVEIRA, E. J. A.; CARVALHO, P. V. V. C.; COSTA, A. N. S. F.; CUNHA, M. C. C.; MELO, G. L.; AZEVEDO, S. M. F. O. Occurrence of saxitoxins and an anatoxin-a(s)-like anticholinesterase in a Brazilian drinking water supply. Harmful Algae, v. 4, n. 4, p. 743-753, 2005. http:/ /dx.doi. org/10.1016/j.hal.2004.11.001.

MOURA, A. N.; NASCIMENTO, E. C.; DANTAS, E. W. Temporal and spatial dynamics of phytoplankton near farm fish in eutrophic reservoir in Pernambuco. Brazil. International Journal of Tropical Biology, v. 60, n. 2, p. 581-597, 2012. PMid:23894931.

MOURA, A. N.; NASCIMENTO, E. C.; DIAS, S. N.; OLIVEIRA, H. S. B.; DANTAS, E. W.; BITTENCOURT-OLIVEIRA, M. C. Diversidade e variação sazonal do fitoplâncton em reservatórios de abastecimento público no estado de Pernambuco. In: MOURA, A. N.; ARAÚJO, E. L.; ALBUQUERQUE, U. P. (Eds.). Biodiversidade, potencial econômico e processos eco-fisiológicos em ecossistemas nordestinos. Recife: Comunigraf, 2008. p. 159-179.

MOURA, A. N.; SEVERIANO, J. S.; TAVARES, N. K. A.; DANTAS, E. W. The role of a cascade of reservoirs and seasonal variation in the phytoplankton structure in a tropical river. Brazilian Journal of Biology $=$ Revista Brasileira de Biologia, v. 73, n. 2, p. 291298, 2013. PMid:23917556. http://dx.doi.org/10.1590/S151969842013000200009.

MOUSTAKA-GOUNI, M.; KORMAS, K. A.; VARDAKA, E.; KATSIAPI, M.; GKELIS, S. Raphidiopsis mediterránea - Skuja represents non-heterocytous life-cycle stages of Cylindrospermopsis raciborskii (Woloszynska) Seenayya et Subba Raju in Lake Kastoria (Greece), its type locality: evidence by morphological and phylogenetic analysis. Harmful Algae, v. 8, n. 6, p. 864-872, 2009. http://dx.doi. org/10.1016/j.hal.2009.04.003.

NOGUEIRA, I. C. G.; PEREIRA, P.; DIAS, E.; PFLUGMACHER, S.; WIEGAND, C.; FRANCA, S.; VASCONCELOS, V. M. Accumulation of paralytic shellfish toxins (PST) from the cyanobacterium Aphanizomenon issatschenkoi by cladoceran Daphnia magna. Toxicon, v. 44, n. 7, p. 773-780, 2005. PMid:15500853. http://dx.doi.org/10.1016/j.toxicon.2004.08.006.

NOGUEIRA, M. G.; FERRAREZE, M.; MOREIRA, M. L.; GOUVEAA, R. M. Phytoplankton assemblages in a reservoir cascade of a large tropical - subtropical river (SE, Brazil). Brazilian Journal of Biology $=$ Revista Brasileira de Biologia, v. 70, n. 3, p. 781-793, 2010. Supplement. PMid:21085783. http://dx.doi.org/10.1590/ S1519-69842010000400009.

O'NEIL, J. M.; DAVIS, T. W.; BURFORD, M. A.; GOBLER, C. J. The rise of harmful cyanobacteria blooms: the potential roles of eutrophication and climate change. Harmful Algae, v. 14, p. 313-334, 2012. http://dx.doi.org/10.1016/j.hal.2011.10.027.

PIZZOLON, L.; TRACANNA, B.; PRÓSPERI, C.; GUERRERO, J. M. Cyanobacterial blooms in Argentinean inland waters. Research Management, v. 4, p. 101-105, 1999.

SAKER, M. L.; GRIFFITHS, D. J. The effect of temperature on growth and cylindrospermopsin content of seven isolates of Cylindrospermopsis raciborskii (Nostocales, Cynophyceae) from water bodies in nortern Australia. Phycologia, v. 39, n. 4, p. 349-354, 2000. http://dx.doi.org/10.2216/i0031-8884-39-4-349.1.

SANT'ANNA, C. L.; AZEVEDO, M. T. P. Contribution to the knowledge of potentially toxic Cyanobacteria from Brazil. Nova Hedwigia, v. 71. p. 359-385, 2000. 
SENERPONT-DOMIS, L. N. Plankton dynamics under different climatic conditions in space and time. Freshwater Biology, v. 58, n. 3, p. 463-482, 2013. http://dx.doi.org/10.1111/fwb.12053.

SHANNON, C. E.; WEAVER, W. The mathematical theory of communication. Urbana: University of Illinois Press, 1949.

WERNER, V.R. Cyanophycea/Cyanobacteria no Sistema de Lagoas e Lagunas da Planície Costeira do Estado do Rio Grande do Sul, Brasil. 2002. 363 f. Tese (Doutorado) - Instituto de Biociência, Universidade Estadual Paulista, Rio Claro, 2002.

WU, Z.; SHI, J.; XIAO, P.; LIU, Y.; LI, R. Phylogenetic analysis of two cyanobacterial genera Cylindrospermopsis and Raphidiopsis based on multi-gene sequences. Harmful Algae, v. 10, n. 5, p. 419-426, 2011. http://dx.doi.org/10.1016/j.hal.2010.05.001.

\section{Authors contributions}

Mario Ubirajara Gonçalves Barros: Data processing and organization, text writing and structuring, interpretation of results.

Ismael Keslley Carloto Lopes: Data processing and organization, text writing and structuring.

Stella Maris de Castro Carvalho: Organization of the methodology, Cyanobacteria count and identification, data gathering and organization.

José Capelo Neto: Data processing and organization, calculation of indexes, text structuring and collaboration in writing the discussion of the results and conclusions. 